\title{
Experimentation of a banded tandem ventilation system with balanced structure
}

\author{
Doru Cioclea*, Ion Gherghe, Emeric Chiuzan, Adrian Matei, and Răzvan Drăgoescu \\ National Institute for Research and Development in Mine Safety and Protection to Explosion - \\ INSEMEX , 32-34, G-ral Vasile Milea Street, Petroșani, Romania
}

\begin{abstract}
The problem of industrial ventilation has arisen as a result of the serious pollution problems of both the industrial areas and the industrial premises. The polluted atmosphere, outside the industrial premises, can penetrate inside them naturally or through ventilation systems. The commissioning of a ventilation system occurs whenever a workplace generates more pollutants than those normally accepted by hygiene of work conditions, safety, health, etc. In order to be able to choose the correct ventilation system, a complete analysis of the workplace to be ventilated must be carried out so that the solution chosen to solve the problem of the exhaust, but also be well received by the user, respecting the thermal comfort of it. The paper presents the results of experimenting with a balanced tandem ventilation system with stable and unstable operation.
\end{abstract}

\section{Experimentation premises}

Experimenting the balanced ventilation system with stable and unstable operation has been carried out in the body for industrial ventilation stands on the tandem fan experimentation stand [1-4].

The testing special tandem fan stand is made up from three fan battery, parallel mounted, for fresh air, which operated in blowing mode, and a three fan battery for evacuation of vicious air, mounted in parallel with operating on an suction mode and which are located on the wall opposite to the one on which the blower fans are mounted [5-7].

The suction and blowing fans are connected to $315 \mathrm{~mm}$ circular tubing. The V1, V2 and V3 suction fans as well as the blowing fans are VAS 315 type.

Standard industrial axial fans VAS designed for the transport of air or gases without corrosive, abrasive or toxic agents, metal dust or suspensions with agglomeration or sticking tendencies. The power supply of the experiment stand is provided by the automation panel fig. 1 .

The fans experimental stand [8-10], which are mounted in tandem, consists in two groups of axial fans, namely:

- fresh air ventilation fan group consisting of two fans of $0.75 \mathrm{~kW}$ and a fan of $0.5 \mathrm{kw}$ fig. 2 ;

\footnotetext{
* Corresponding author: doru.cioclea@insemex.ro
} 
- the exhaust fans group consisting of two fans of $0.75 \mathrm{kw}$ and a fan of $0.5 \mathrm{kw}$ fig. 3 ;

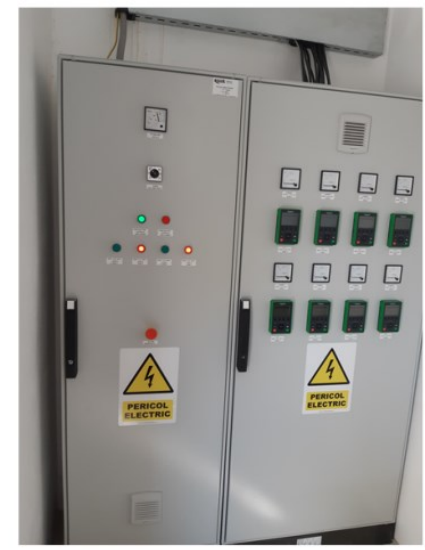

Fig. 1. Power supply and automation panel.

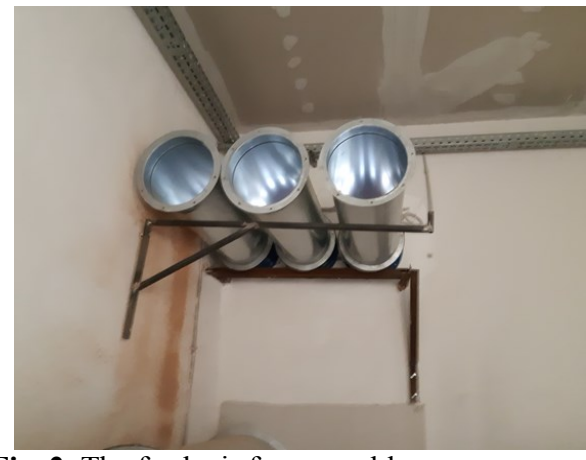

Fig. 2. The fresh air fan assembly.

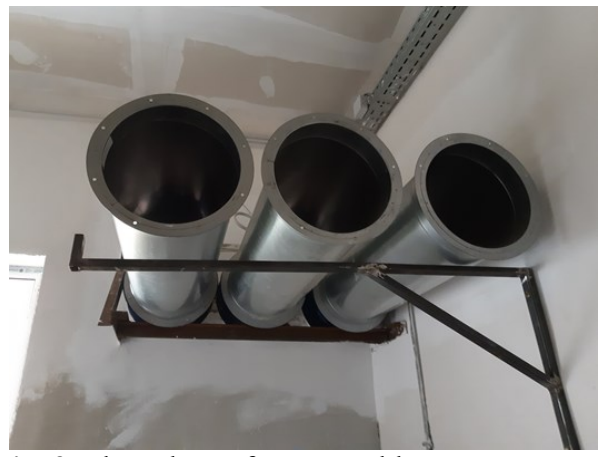

Fig. 3. The exhaust fans assembly.

The entire ventilation system is controlled by a SCADA control and control program, fig. 4. Individual fans are controlled by frequency converters fig. 5 .

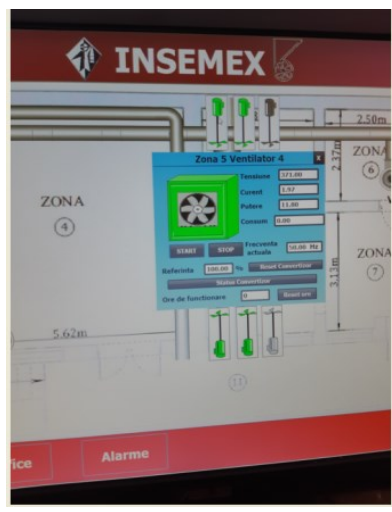

Fig. 4. SCADA command and control program.

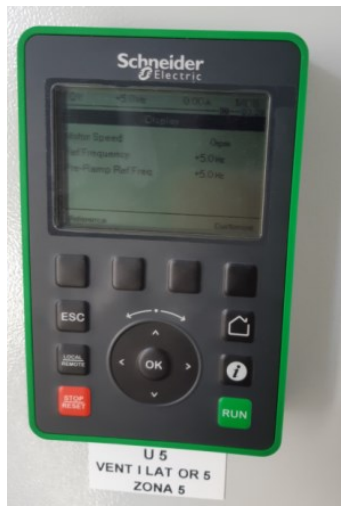

Fig. 5. Frequency converters. 


\section{Measurement results}

For the experimentation of the balanced ventilation system with stable and unstable operation, measurements were made on the experimental stand of fans mounted in tandem in six variants, namely:

- Experimenting the ventilation system in a stable condition, when the $0.75 \mathrm{~kW}$ blowing fans and the $0.75 \mathrm{~kW}$ suction fans are switched on;

- Experimenting the ventilation system in a stable condition where a $0.75 \mathrm{~kW}$ blowing fan and a $0.75 \mathrm{~kW}$ suction fan are switched on;

- Experimenting the ventilation system in a stable condition when the $0.5 \mathrm{~kW}$ blowing fan and the $0.5 \mathrm{~kW}$ suction fan are switched on;

- Unstable ventilation system experimentation when $0.75 \mathrm{~kW}$ blowing fans and $0.75 \mathrm{~kW}$ suction fans are switched on;

- Unstable ventilation system experimentation when a $0.75 \mathrm{~kW}$ blowing fan and a $0.75 \mathrm{~kW}$ suction are switched on;

- Unstable ventilation system experimentation when the $0.5 \mathrm{~kW}$ blowing fan and the $0.5 \mathrm{~kW}$ suction are switched on.

- Measurements were made at an air temperature of $17.0^{\circ} \mathrm{C}$ and air humidity of $43 \%$.

\subsection{Experimenting the ventilation system in a stable condition, when the $\mathbf{0 . 7 5}$ $\mathrm{kW}$ blowing fans $V_{1 \mathrm{i}}, \mathrm{V}_{2 \mathrm{i}}$ and the $0.75 \mathrm{~kW}$ suction fans $\mathrm{V}_{1 \mathrm{e}}, \mathrm{V}_{2 \mathrm{e}}$ are switched on}

For the experimentation, measurements were made at the level of each duct for determining the air velocity and the depression developed by the active fans. The results of the measurements are shown in table no. 1.

Table 1. The results of experimenting the ventilation system in a stable condition, when the $0.75 \mathrm{~kW}$ blowing fans $\mathrm{V}_{1 \mathrm{i}}, \mathrm{V}_{2 \mathrm{i}}$ and the $0.75 \mathrm{~kW}$ suction fans $\mathrm{V}_{1 \mathrm{e}}, \mathrm{V}_{2 \mathrm{e}}$ are switched on

\begin{tabular}{|c|c|c|c|c|c|c|c|c|}
\hline No. & $\begin{array}{l}\text { Technical } \\
\text { data }\end{array}$ & $\mathbf{V}_{\mathbf{i i}}$ & $\mathbf{V}_{\mathbf{2 i}}$ & $\mathbf{V}_{3 \mathbf{i}}$ & $\mathbf{V}_{\mathbf{1 e}}$ & $\mathbf{V}_{\mathbf{2 e}}$ & $\mathbf{V}_{\mathbf{3 e}}$ & $\begin{array}{c}\text { Recir } \\
\text { cu- } \\
\text { lation }\end{array}$ \\
\hline 1 & $\varnothing(\mathrm{mm})$ & 315 & 315 & 315 & 315 & 315 & 315 & \\
\hline 2 & $\mathrm{~S}\left(\mathrm{~m}^{2}\right)$ & 0.0779 & 0.0779 & 0.0779 & 0.0779 & 0.0779 & 0.0779 & \\
\hline 3 & $\mathrm{~V}(\mathrm{~m} / \mathrm{s})$ & 12.4 & 15.7 & 0 & 13.5 & 17.5 & -0.42 & \\
\hline 4 & $\mathrm{Q}(\mathrm{m} 3 / \mathrm{s})$ & 0.96 & 1.22 & 0 & 1.05 & 1.36 & -0.03 & 0.26 \\
\hline 5 & $\mathrm{Q}\left(\mathrm{m}^{3} / \mathrm{min}\right)$ & 57.96 & 73.38 & 0 & 63.09 & 81.79 & -1.96 & 15.7 \\
\hline 6 & $\Delta \mathrm{H}(\mathrm{daPa})$ & 0.4 & 0.4 & 0 & -15 & -20 & 0.4 & \\
\hline 7 & $\mathrm{P}_{\mathrm{n}}(\mathrm{kw})$ & 0.75 & 0.75 & 0.5 & 0.75 & 0.75 & 0.5 & \\
\hline 8 & $\mathrm{P}_{\mathrm{a}}(\mathrm{kw})$ & 0.79 & 0.78 & 0 & 0.78 & 0.81 & 0 & \\
\hline 9 & $\mathrm{U}(\mathrm{V})$ & 373 & 377 & 0 & 374 & 374 & 0 & \\
\hline 10 & $\mathrm{I}(\mathrm{A})$ & 1.53 & 1.51 & 0 & 1.52 & 1,58 & 0 & \\
\hline 11 & $\mathrm{f}(\mathrm{Hz})$ & 50 & 50 & 0 & 50 & 50 & 0 & \\
\hline
\end{tabular}

\subsection{Experimenting the ventilation system in a stable condition where a $\mathbf{0 . 7 5}$ $\mathrm{kW}$ blowing fan $\mathrm{V}_{2 \mathrm{i}}$ and a $0.75 \mathrm{~kW}$ suction fan $\mathrm{V}_{2 \mathrm{e}}$ are switched on}

For the experimentation, measurements were made at the level of each duct for determining the air velocity and the depression developed by the active fans. The results of the measurements are shown in table no. 2 . 
Table 2. The results of experimenting the ventilation system in a stable condition where a $0.75 \mathrm{~kW}$ blowing fan $\mathrm{V}_{2 \mathrm{i}}$ and a $0.75 \mathrm{~kW}$ suction fan $\mathrm{V}_{2 \mathrm{e}}$ are switched on

\begin{tabular}{|c|c|c|c|c|c|c|c|c|}
\hline No. & $\begin{array}{c}\text { Technicat } \\
\text { data }\end{array}$ & $\mathbf{V}_{\mathbf{1 i}}$ & $\mathbf{V}_{\mathbf{2 i}}$ & $\mathbf{V}_{\mathbf{3 i}}$ & $\mathbf{V}_{\mathbf{1 e}}$ & $\mathbf{V}_{\mathbf{2 e}}$ & $\mathbf{V}_{\mathbf{3 e}}$ & $\begin{array}{c}\text { Recircu- } \\
\text { lation }\end{array}$ \\
\hline 1 & $\varnothing(\mathrm{mm})$ & 315 & 315 & 315 & 315 & 315 & 315 & \\
\hline 2 & $\mathrm{~S}\left(\mathrm{~m}^{2}\right)$ & 0.0779 & 0.0779 & 0.0779 & 0.0779 & 0.0779 & 0.0779 & \\
\hline 3 & $\mathrm{~V}(\mathrm{~m} / \mathrm{s})$ & 0.28 & 14.11 & 0 & 0.70 & 17.47 & 0 & \\
\hline 4 & $\mathrm{Q}(\mathrm{m} 3 / \mathrm{s})$ & 0.02 & 1.09 & 0 & 0.05 & 1.36 & 0 & 0.33 \\
\hline 5 & $\mathrm{Q}\left(\mathrm{m}^{3} / \mathrm{min}\right)$ & 1.31 & 65.95 & 0 & 3.27 & 81.65 & 0 & 20.28 \\
\hline 6 & $\Delta \mathrm{H}(\mathrm{daPa})$ & 0.5 & 10.6 & 0 & 0.6 & -12.6 & 0 & \\
\hline 7 & $\mathrm{P}_{\mathrm{n}}(\mathrm{kw})$ & 0.75 & 0.75 & 0.5 & 0.75 & 0.75 & 0.5 & \\
\hline 8 & $\mathrm{P}_{\mathrm{a}}(\mathrm{kw})$ & 0 & 0.79 & 0 & 0 & 0.82 & 0 & \\
\hline 9 & $\mathrm{U}(\mathrm{V})$ & 0 & 374 & 0 & 0 & 372 & 0 & \\
\hline 10 & $\mathrm{I}(\mathrm{A})$ & 0 & 1.54 & 0 & 0 & 1.61 & 0 & \\
\hline 11 & $\mathrm{f}(\mathrm{Hz})$ & 0 & 50 & 0 & 0 & 50 & 0 & \\
\hline
\end{tabular}

\subsection{Experimenting the ventilation system in a stable condition when the $\mathbf{0 . 5}$ $\mathrm{kW}$ blowing fan $\mathrm{V}_{3 \mathrm{i}}$ and the $0.5 \mathrm{~kW}$ suction fan $\mathrm{V}_{3 \mathrm{e}}$ are switched on}

For the experimentation, measurements were made at the level of each duct for determining the air velocity and the depression developed by the active fans. The results of the measurements are shown in table no. 3 .

Table 3. The results of experimenting the ventilation system in a stable condition when the $0.5 \mathrm{~kW}$ blowing fan $\mathrm{V}_{3 \mathrm{i}}$ and the $0.5 \mathrm{~kW}$ suction fan $\mathrm{V}_{3 \mathrm{e}}$ are switched on

\begin{tabular}{|c|c|c|c|c|c|c|c|c|}
\hline No. & $\begin{array}{c}\text { Fan } \\
\text { Technical } \\
\text { data }\end{array}$ & $\mathbf{V}_{\mathbf{1 i}}$ & $\mathbf{V}_{\mathbf{2 i}}$ & $\mathbf{V}_{\mathbf{3 i}}$ & $\mathbf{V}_{\mathbf{1 e}}$ & $\mathbf{V}_{\mathbf{2 e}}$ & $\mathbf{V}_{\mathbf{3 e}}$ & $\begin{array}{c}\text { Recircu- } \\
\text { lation }\end{array}$ \\
\hline 1 & $\varnothing(\mathrm{mm})$ & 315 & 315 & 315 & 315 & 315 & 315 & \\
\hline 2 & $\mathrm{~S}\left(\mathrm{~m}^{2}\right)$ & 0.0779 & 0.0779 & 0.0779 & 0.0779 & 0.0779 & 0.0779 & \\
\hline 3 & $\mathrm{~V}(\mathrm{~m} / \mathrm{s})$ & 0.36 & 0 & 13.5 & 0.79 & 0.26 & 16.3 & \\
\hline 4 & $\mathrm{Q}(\mathrm{m} 3 / \mathrm{s})$ & 0.03 & 0 & 1.05 & 0.06 & 0.02 & 1.26 & 0.32 \\
\hline 5 & $\mathrm{Q}\left(\mathrm{m}^{3} / \mathrm{min}\right)$ & 1.68 & 0 & 63.09 & 3.69 & 1.21 & 76.18 & 19.67 \\
\hline 6 & $\Delta \mathrm{H}(\mathrm{daPa})$ & -0.4 & 0 & 10.3 & 0.5 & 0.4 & -21.5 & \\
\hline 7 & $\mathrm{P}_{\mathrm{n}}(\mathrm{kw})$ & 0.75 & 0.75 & 0.5 & 0.75 & 0.75 & 0.5 & \\
\hline 8 & $\mathrm{P}_{\mathrm{a}}(\mathrm{kw})$ & 0 & 0 & 0.65 & 0 & 0 & 0.68 & \\
\hline 9 & $\mathrm{U}(\mathrm{V})$ & 0 & 0 & 374 & 0 & 0 & 372 & \\
\hline 10 & $\mathrm{I}(\mathrm{A})$ & 0 & 0 & 1.01 & 0 & 0 & 1.06 & \\
\hline 11 & $\mathrm{f}(\mathrm{Hz})$ & 0 & 0 & 50 & 0 & 0 & 50 & \\
\hline
\end{tabular}

\subsection{Unstable ventilation system experimentation when $0.75 \mathrm{~kW}$ blowing fans $V_{1 \mathrm{i}}, V_{2 \mathrm{i}}$ and $0.75 \mathrm{~kW}$ suction fans $V_{1 \mathrm{e}}, \mathrm{V}_{2 \mathrm{e}}$ are switched on}

For the experimentation, measurements were made at the level of each duct for determining the air velocity and the depression developed by the active fans. The results of the measurements are shown in table no. 4. 
Table 4. The results of unstable ventilation system experimentation when $0.75 \mathrm{~kW}$ blowing fans $\mathrm{V}_{1 \mathrm{i}}$, $\mathrm{V}_{2 \mathrm{i}}$ and $0.75 \mathrm{~kW}$ suction fans $\mathrm{V}_{1 \mathrm{e}}, \mathrm{V}_{2 \mathrm{e}}$ are switched on

\begin{tabular}{|c|c|c|c|c|c|c|c|c|}
\hline No. & $\begin{array}{c}\text { Fan } \\
\text { Technical } \\
\text { data }\end{array}$ & $\mathbf{V}_{\mathbf{1 i}}$ & $\mathbf{V}_{\mathbf{2 i}}$ & $\mathbf{V}_{\mathbf{3 i}}$ & $\mathbf{V}_{\mathbf{1 e}}$ & $\mathbf{V}_{\mathbf{2 e}}$ & $\mathbf{V}_{\mathbf{3 e}}$ & $\begin{array}{c}\text { Recircu- } \\
\text { lation }\end{array}$ \\
\hline 1 & $\varnothing(\mathrm{mm})$ & 315 & 315 & 315 & 315 & 315 & 315 & \\
\hline 2 & $\mathrm{~S}\left(\mathrm{~m}^{2}\right)$ & 0.0779 & 0.0779 & 0.0779 & 0.0779 & 0.0779 & 0.0779 & \\
\hline 3 & $\mathrm{~V}(\mathrm{~m} / \mathrm{s})$ & 12.0 & 14.45 & 0.22 & 13.7 & 17.25 & 0.51 & \\
\hline 4 & $\mathrm{Q}(\mathrm{m} 3 / \mathrm{s})$ & 0.93 & 1.12 & 0.02 & 1.07 & 1.34 & 0.04 & 0.4 \\
\hline 5 & $\mathrm{Q}\left(\mathrm{m}^{3} / \mathrm{min}\right)$ & 56.08 & 67.53 & 1.03 & 64.03 & 80.62 & 2.38 & 24.45 \\
\hline 6 & $\Delta \mathrm{H}(\mathrm{daPa})$ & 0.6 & 1.1 & -0.5 & -25.7 & -29.4 & 0.4 & \\
\hline 7 & $\mathrm{P}_{\mathrm{n}}(\mathrm{kw})$ & 0.75 & 0.75 & 0.5 & 0.73 & 0.76 & 0.5 & \\
\hline 8 & $\mathrm{P}_{\mathrm{a}}(\mathrm{kw})$ & 0.72 & 0.76 & 0 & 0.78 & 0.81 & 0 & \\
\hline 9 & $\mathrm{U}(\mathrm{V})$ & 372 & 376 & 0 & 372 & 373 & 0 & \\
\hline 10 & $\mathrm{I}(\mathrm{A})$ & 1.41 & 1.46 & 0 & 1.42 & 1.48 & 0 & \\
\hline 11 & $\mathrm{f}(\mathrm{Hz})$ & 50 & 50 & 0 & 50 & 50 & 0 & \\
\hline
\end{tabular}

\subsection{Unstable ventilation system experimentation when a $0.75 \mathrm{~kW}$ blowing fan $V_{2 i}$ and a $0.75 \mathrm{~kW}$ suction fan $V_{2 \mathrm{e}}$ are switched on}

For the experimentation, measurements were made at the level of each duct for determining the air velocity and the depression developed by the active fans. The results of the measurements are shown in table no. 5 .

Table 5. The results of unstable ventilation system experimentation when a $0.75 \mathrm{~kW}$ blowing fan $\mathrm{V}_{2 \mathrm{i}}$ and a $0.75 \mathrm{~kW}$ suction fan $\mathrm{V}_{2 \mathrm{e}}$ are switched on

\begin{tabular}{|c|c|c|c|c|c|c|c|c|}
\hline No. & $\begin{array}{c}\text { Fechnicat } \\
\text { data }\end{array}$ & $\mathbf{V}_{\mathbf{1 i}}$ & $\mathbf{V}_{\mathbf{2 i}}$ & $\mathbf{V}_{\mathbf{3 i}}$ & $\mathbf{V}_{\mathbf{i e}}$ & $\mathbf{V}_{\mathbf{2 e}}$ & $\mathbf{V}_{\mathbf{3 e}}$ & $\begin{array}{c}\text { Recircu- } \\
\text { lation }\end{array}$ \\
\hline 1 & $\varnothing(\mathrm{mm})$ & 315 & 315 & 315 & 315 & 315 & 315 & \\
\hline 2 & $\mathrm{~S}\left(\mathrm{~m}^{2}\right)$ & 0.0779 & 0.0779 & 0.0779 & 0.0779 & 0.0779 & 0.0779 & \\
\hline 3 & $\mathrm{~V}(\mathrm{~m} / \mathrm{s})$ & 0.21 & 11.07 & 0 & 0.30 & 17.21 & 0 & \\
\hline 4 & $\mathrm{Q}(\mathrm{m} 3 / \mathrm{s})$ & 0.01 & 0.86 & 0 & 0.02 & 1.34 & 0 & 0.51 \\
\hline 5 & $\mathrm{Q}\left(\mathrm{m}^{3} / \mathrm{min}\right)$ & 0.98 & 51.74 & 0 & 1.40 & 80.43 & 0 & 31.07 \\
\hline 6 & $\Delta \mathrm{H}(\mathrm{daPa})$ & -0.5 & 7.4 & 0 & 0.6 & -33.2 & 0 & \\
\hline 7 & $\mathrm{P}_{\mathrm{n}}(\mathrm{kw})$ & 0.75 & 0.75 & 0.55 & 0.75 & 0.75 & 0.55 & \\
\hline 8 & $\mathrm{~Pa}(\mathrm{kw})$ & 0 & 0.72 & 0 & 0 & 0.83 & 0 & \\
\hline 9 & $\mathrm{U}(\mathrm{V})$ & 0 & 375 & 0 & 0 & 373 & 0 & \\
\hline 10 & $\mathrm{I}(\mathrm{A})$ & 0 & 1.40 & 0 & 0 & 1.61 & 0 & \\
\hline 11 & $\mathrm{f}(\mathrm{Hz})$ & 0 & 50 & 0 & 0 & 50 & 0 & \\
\hline
\end{tabular}

\subsection{Unstable ventilation system experimentation when the $0.5 \mathrm{~kW}$ blowing fan $\mathrm{V}_{3 \mathrm{i}}$ and the $0.5 \mathrm{~kW}$ suction fan $\mathrm{V}_{3 \mathrm{e}}$ are switched on}

For the experimentation, measurements were made at the level of each duct for determining the air velocity and the depression developed by the active fans. The results of the measurements are shown in table no. 6 . 
Table 6. The results of unstable ventilation system experimentation when the $0.5 \mathrm{~kW}$ blowing fan $\mathrm{V}_{3 \mathrm{i}}$ and the $0.5 \mathrm{~kW}$ suction fan $\mathrm{V}_{3 \mathrm{e}}$ are switched on

\begin{tabular}{|c|c|c|c|c|c|c|c|c|}
\hline No. & $\begin{array}{c}\text { Fan } \\
\text { Technical } \\
\text { data }\end{array}$ & $\mathbf{V}_{\mathbf{1 i}}$ & $\mathbf{V}_{\mathbf{2 i}}$ & $\mathbf{V}_{\mathbf{3 i}}$ & $\mathbf{V}_{\mathbf{1 e}}$ & $\mathbf{V}_{\mathbf{2 e}}$ & $\mathbf{V}_{\mathbf{3 e}}$ & $\begin{array}{c}\text { Recircu- } \\
\text { lation }\end{array}$ \\
\hline 1 & $\varnothing(\mathrm{mm})$ & 315 & 315 & 315 & 315 & 315 & 315 & \\
\hline 2 & $\mathrm{~S}\left(\mathrm{~m}^{2}\right)$ & 0.0779 & 0.0779 & 0.0779 & 0.0779 & 0.0779 & 0.0779 & \\
\hline 3 & $\mathrm{~V}(\mathrm{~m} / \mathrm{s})$ & 0.46 & 0 & 12.2 & 0.67 & 0.41 & 16.75 & \\
\hline 4 & $\mathrm{Q}(\mathrm{m} 3 / \mathrm{s})$ & 0.03 & 0 & 0.95 & 0.05 & 0.03 & 1.30 & 0.55 \\
\hline 5 & $\mathrm{Q}\left(\mathrm{m}^{3} / \mathrm{min}\right)$ & 2.15 & 0 & 57.02 & 3.13 & 1.91 & 78.28 & 28.45 \\
\hline 6 & $\Delta \mathrm{H}(\mathrm{daPa})$ & -0.6 & 0 & 8.3 & 0.5 & 0.4 & -25.5 & \\
\hline 7 & $\mathrm{P}_{\mathrm{n}}(\mathrm{kw})$ & 0.75 & 0.75 & 0.55 & 0.75 & 0.75 & 0.55 & \\
\hline 8 & $\mathrm{P}_{\mathrm{a}}(\mathrm{kw})$ & 0 & 0 & 0.47 & 0 & 0 & 0.55 & \\
\hline 9 & $\mathrm{U}(\mathrm{V})$ & 0 & 0 & 377 & 0 & 0 & 378 & \\
\hline 10 & $\mathrm{I}(\mathrm{A})$ & 0 & 0 & 0.91 & 0 & 0 & 1.06 & \\
\hline 11 & $\mathrm{f}(\mathrm{Hz})$ & 0 & 0 & 50 & 0 & 0 & 50 & \\
\hline
\end{tabular}

\section{Results interpretation}

After the experiments we can draw the following conclusions, namely:

- In the case of stable ventilation systems experimentations:

- speeds have been determined at the level of air ducts for active fans between 12.4$17.5 \mathrm{~m} / \mathrm{s}$;

- air flows ranged from 57.96 to $81.79 \mathrm{~m}^{3} / \mathrm{min}$;

- recirculation air flows rates ranged between $15.7-20.28 \mathrm{~m}^{3} / \mathrm{min}$;

- the developed pressures were between $0.4-21.5 \mathrm{daPa}$;

- In the unstable experimentation of ventilation systems at the level of the ducts for active fans:

- the speeds were between $11.07-17.25 \mathrm{~m} / \mathrm{s}$;

- the air flow rates varied from 51.74 to $80.62 \mathrm{~m}^{3} / \mathrm{min}$;

- recirculation air flow rates ranged from 24.45 to $31.07 \mathrm{~m}^{3} / \mathrm{min}$;

- the developed pressures were between 0.4 - $33.2 \mathrm{daPa}$;

Generally, the variation of the recirculation air flows determined during the experimentation of the ventilation systems in the stable mode is proportional to the variation of the recirculation air flows determined during the experimentation of the ventilation systems in the unstable mode, fig. 6 .

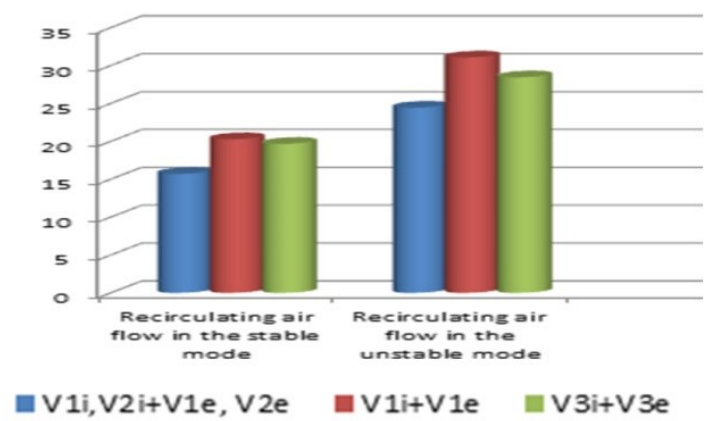

Fig. 6. Variation of the recirculation air flows. 


\section{Conclusions}

- Experimentation of the balanced ventilation system with stable and unstable operation was carried out in the body for the industrial ventilation stands on the experimental stand of fans mounted in tandem;

- For the experimentation of the balanced ventilation system with stable and unstable operation, measurements were carried out which included combinations of fans in six functional variants;

- In the stable and unstable experiments of the ventilation systems the speeds at the level of the active fan ducts, the air flow rates, the recirculation, the pressures developed, the current and the supply voltage as well as the absorbed power were determined;

- The variation of the recirculation air flows determined during the experimentation of the ventilation systems in the stable mode is proportional to the variation of the recirculation air flows determined during the experimentation of the ventilation systems in the unstable mode.

This paper was developed within the Nucleu - Programme, carried out with the support of ANCSI, project no. PN-19-21-02-04

\section{References}

1. F. Băltărețu, I. Matei, Ghid practic pentru proiectarea și verificarea instalațiilor de aeraj parțial (Ministerul Minelor, Petrolului și Geologiei, Romania,1987)

2. B. Biegert, J. Railio, Terminology, Industrial ventilation design guidebook (Academic Press, San Diego, California, USA, 2001)

3. D. Cioclea, C. Lupu, I. Gherghe, Ghid pentru dimensionarea instalațiilor de ventilație industrială, (Editura INSEMEX, Petrosani, Romania, 2013)

4. A. Cristea, Ventilarea și condiționarea aerului, I, (Editura Tehnică, București, Romania, 1968)

5. A. Cristea, N. Niculescu, Ventilarea și condiționarea aerului, II, (Editura Tehnică, București, Romania, 1971)

6. A. Cristea, T.Ș. Terețean, Ventilarea și condiționarea aerului, III, (Editura Tehnică, București, Romania, 1976)

7. H. Goodfellow, E. Tahti, Industrial ventilation design guidebook, (Academic Press, San Diego, California, USA2001)

8. N.Niculescu, Gh. Duță, P. Stoenescu, I. Colda, Instalații de ventilare și climatizare, (E.D.P., București, 1982).

9. O. Bancea, Sisteme de ventilare industrială, (Editura Politehnică, Timișoara, 2009)

10. F. Rădoi, Proceedings of Universitaria SIMPRO 2016, Petrosani, Romania, (2016). 